\title{
Layanan Persampahan di Kota Surakarta dengan Pemetaan Barbasis Sistem Informasi Geografis
}

\author{
Rudy Yoga Lesmana \\ Dosen Program Studi Teknik Lingkungan Universitas Muhammadiyah Palangkaraya
}

\begin{abstract}
ABSTRAK
Pemetaan Sistem Informasi Geografis untuk layanan persampahan di Kota Surakarta saat ini sudah menjadi sesuatu yang sangat dibutuhkan dalam pengambilan keputusan dibidang perencanaan maupun pengelolaan persampahan di kota Surakarta, mengingat masih banyaknya masyarakat Kota Surakarta yang belum mengetahui sistem informasi persampahan tersebut. Penelitian ini bertujuan Untuk memetakan kuantitas sampah, kualitas pelayanan persampahan dan mengetahui kontinuitas pelayanan persampahan di Kota Surakarta berbasis sistem informasi geografis. Penelitian dilakukan di kota Surakarta, yang mempunyai luas wilayah sebesar 44,04 $\mathrm{Km}^{2}$. Data penelitian meliputi Peta RBI Kota Surakarta dari Badan Informasi Geospasial dan data persampahan dari Dinas Pertamanan dan kebersihan Kota Surakarta. Metode yang digunakan adalah metode observasi, pemetaan dan metode wawancara. Tahapan pengolahan data yaitu dengan memasukan data-data yang persampahan yang berasal dari instansi terkait ke dalam Software ArcView 3.3 untuk membuat peta layanan persampahan Kota Surakarta. Berdasarkan hasil analisis, kondisi timbulan sampah di Kota Surakarta pada tahun 2013 diprediksi sebesar 305,516 ton/hari. Persentase Pelayanan persampahan diperkirakan mencapai $86 \%$ dan akan mengalami peningkatan menjadi $92 \%$ pada tahun 2022. Untuk kontinuitas pelayanan persampahan diperlukan fasilitas seperti kontainer sampah. Pada tahun 2013 terdapat sebanyak 131 unit kontainer dan harus melakukan program Reduce, Reuse dan Recyle (3R) sebanyak 150,84 sampah $/ \mathrm{m}^{3} /$ hari, sehingga pada tahun 2022 sampah $3 \mathrm{R}$ sebesar $581.71 \mathrm{~m}^{3} /$ hari. Dengan melakukan pemetaan untuk layanan persampahan, masyararakat dapat mengetahui kondisi persampahan yang ada dan diharapkan dapat menangani masalah persampahan yang ada di Kota Surakarta.
\end{abstract}

Kata kunci: Sistem Informasi Lingkungan (SIL), kuantitas, sampah, kontinyuitas, pelayanan

\section{PENDAHULUAN}

Perkembangan teknologi informasi dan komunikasi yang begitu cepat, merupakan suatu peluang dalam mendiseminasikan informasi secara cepat dan akurat kepada masyarakat. Penggunaan media elektronik kenyataannya merupakan sarana yang efektif dalam pendistribusian informasi (KEMENLH, 2009). Kurangnya informasi mengenai data persampahan membuat masyarakat kurang menetahui informasi yang berkaitan dengan layanan persampahan.

Sampah menurut Tchobanoglous et al., (1993) adalah bahan buangan yang berbentuk padat maupun semi padat yang berasal dari aktifitas manusia maupun hewan yang dibuang karena tidak memiliki manfaat bagi pemiliknya. Menurut Darmasetiawan (2004), beberapa sumber sampah yang dijadikan sebagai acuan yaitu: (a) sumber sampah yang 
berasal dari perumahan masyarakat berpenghasilan tinggi, sedang dan rendah, (b) sumber sampah yang berasal dari daerah komersil seperti pasar, hotel, restoran, (c) sumber sampah yang berasal dari fasilitas umum seperti perkantoran, sekolah, rumah sakit, gedung olah raga, museum, taman, jalan, sungai, (e) sumber sampah yang berasal dari fasilitas sosial seperti rumah jompo, panti asuhan serta tempat ibadah dan (e) sumber-sumber lain.

Sampah menurut Bahar (1986), dapat dibagi atas dua golongan, yaitu: (a) sampah yang mudah terurai (degradable refuse) secara alami melalui proses fisik, kimiawi, maupun biologis. sampah golongan ini berasal dari bahan organik, seperti sayuran, sisa makanan, kertas, bangkai binatang, dan (b) sampah yang tidak mudah terurai berasal dari bahan-bahan non organik seperti metal, kaca, plastik, kayu, keramik.

Timbulan sampah yang dihasilkan dari suatu kota pada dasarnya sangat ditentukan oleh seluruh aktifitas masyarakat dikota tersebut. Aktifitas tersebut meliputi perdagangan, perumahan, perkantoran, perindustrian, pertanian dll. Untuk timbulan sampah, pada umumnya dipakai ukuran volume $\left(\mathrm{m}^{3} / \mathrm{hari}\right)$ atau berat (ton/hari) (Darmasetiawan, 2004).

Salah satu TPA yang ada di Kota Surakarta yaitu TPA Putri Cempo, TPA tersebut sudah mulai beroperasi mulai tahun 1987 dan dapat menampung sampah sebesar 100.000 ton, dan memiliki luas $17 \mathrm{Ha}$. Sampah yang dibuang ke TPA tersebut tiap tahunnya mengalami peningkatan. Peningkatan volume sampah disebabkan oleh pertambahan jumlah penduduk yang berimbas pada besarnya sampah yang dibuang ke TPA. Peningkatan sampah tersebut akan berimbas bagi berkurangnya umur layan TPA (Ratih, 2011). Ditinjau dari permasalahan di atas perlu diupayakan pengelolaan sampah dengan cara memberikan informasi tentang pelayanan persampahan di kota Surakarta yaitu dengan melakukan pemetaan yang berbasis Sistem Informasi Geografis sehingga timbulan sampah dapat diminimalkan. Sistem Informasi Geografis adalah sistem komputer yang digunakan untuk memasukkan, menyimpan, mengintegrasikan, memanipulasi, menganalisa, dan menampilkan data yang berhubungan dengan posisi-posisi di permukaan bumi (Prahasta, 2002).

Penelitian ini bertujuan untuk: (a) mengetahui jumlah timbulan sampah yang ada di Kota Surakarta, (b) mengetahui kualitas pelayanan persampahan di Kota Surakarta, (c) mengetahui Kontinuitas pelayanan persampahan di Kota Surakarta dan (4) memberikan data kepada masyarakat mengenai informasi pelayanan persampahan berbasis Sistem Informasi Geografis di Kota Surakata

\section{METODE PENELITIAN \\ Lokasi dan Waktu Penelitian}

Penelitian dilakukan di Kota Surakarta yang Secara geografis terletak di antara $110^{\circ} 45^{\prime} 15^{\prime \prime}-110^{\circ} 45^{\prime} 35^{\prime \prime}$ BT dan $7^{\circ} 36^{\prime} 00^{\prime \prime}$ 756'00'"LS.

\section{Jenis Penelitian}

Penelitian ini termasuk penelitian deskriptif kualitatif, yang bertujuan untuk mendeskripsikan kondisi persampahan di Kota Surakarta.

\section{Batasan Operasional}

Dalam batasan operasional, data yang digunakan untuk penelitian terdiri dari:

a) Volume Sampah Penduduk

Besarnya timbulan sampah yang dihasilkan berasal dari penduduk yang berdomisisli di kota Surakarta, dan tidak mengidentifikasi sampah yang dibawa oleh penduduk yang berasal dari kota lain di sekitar kota Surakarta. Volume sampah dari dihitung berdasarkan waktu harian (Ton/hari)

b) Volume Sampah Pasar

Sampah yang dihitung berasal dari kegiatan perdagangan yang ada di pasar di kota Surakarta, selain dari sampah yang dihasilkan penduduk

c) Tidak Ada Pemilahan Sampah

Sampah yang dihasilkan dari penduduk dan sampah pasar, tidak dilakukan pemilahan di tingkat kelurahan maupun kecamatan.

d) Persentase Layanan

Persentase layanan persampahan di dasarkan pada sampah yang dihasilkan penduduk dan bukan yang berasal dari sampah pasar 


\section{Analisis Data}

Penelitian ini menggunakan analisis kualitatif, langkah-langkahnya yaitu sebagai berikut (Miles dan Huberman dalam Sugiyono, 2011):

a) Reduksi Data (Data Reduction)

Data yang akan direduksi adalah hasil wawancara, sehingga untuk mempermudah peneliti dalam melakukan pengumpulan data selanjutnya

b) Penyajian Data (Data Display)

Data akan disajikan dalam bentuk peta yang terlebih dahulu dianalisis menggunakan analisis spasial Sistem Informasi Geografis (SIG).

c) Analisis Spasial Sistem Informasi Geografis

Dilakukan dengan menggunakan analisis spasial yang merupakan fungsi dari SIG (Prahasta, 2002).

\section{Tahap Penelitian}

a) Pembuatan basis data (tabular)

Basis data berfungsi untuk menyimpan, mencari, dan terkoneksi ke aplikasi sistem informasinya.

b) Pengolahan Data Spasial

Melakukan proses editing peta Kota Surakarta, seperti dijitasi peta, kemudian mengkonversi dari format .dwg ke format shapefile atau .shp.
HASIL DAN PEMBAHASAN Kuantitas Sampah di Kota Surakarta

Kuantitas sampah merupakan jumlah timbulan sampah yang dihasilkan dari aktivitas per orang/hari.

\section{Timbulan Sampah Total Kota Surakarta}

Jika data timbulan sampah belum tersedia, maka dapat mengacu pada SNI 193964-1994 yaitu: Kota besar 2 - 2,5 liter/org/hari atau $0,4-0,5 \mathrm{~kg} / \mathrm{org} / \mathrm{hari}$.

\section{Timbulan Sampah Terlayani Kota Surakarta}

Pada Tahun 2013 jumlah penduduk kota Surakarta yang terlayani fasilitas persampahan sebesar 536.336 jiwa dan selalu lebih kecil dari jumlah penduduk total, karena tidak semua tempat pembuangan sementara tersebar merata. Penduduk yang terlayani dan jumlah timbulan sampah pada tahun 2013 disajikan pada Tabel 1.

Tabel 1 merupakan jumlah timbulan sampah yang tersebar di lima Kecamatan di kota Surakarta, semakin besar jumlah penduduk, maka semakin besar pula timbulan sampah yang akan dihasilkan, Kecamatan dengan timbulan sampah terbesar yaitu Kecamatan Banjarsari, dengan timbulan sampah sebesar 479,9625 $\mathrm{m}^{3}$. Timbulan sampah terkecil, terdapat di Kecamatan Serengan, dengan jumlah timbulan sampah sebesar $158,5975 \mathrm{~m}^{3}$

Tabel 1. jumlah timbulan sampah yang tersebar di lima Kecamatan di kota Surakarta

\begin{tabular}{lllllll}
\hline Keterangan & Laweyan & Banjarsari & Jebres & Ps.Kliwon & Serengan & Total \\
\hline $\begin{array}{l}\text { Penduduk Total } \\
\text { Timbulan Sampah }\end{array}$ & 120.610 & 191.985 & 145.814 & 89183 & 63439 & 611.031 \\
l/org/hari & & & & & \\
Total m3/hari & 2,50 & 2,50 & 2,50 & 2,50 & 2,50 \\
Kg/org/hari & 301,525 & 479,9625 & 364,535 & 222,9575 & 158,5975 \\
Total kg/hari & 0,50 & 0,50 & 0,50 & 0,50 & 0,50 \\
Penduduk Terlayani & 60.305 & $95.992,5$ & 72.907 & $44.591,5$ & 31.719 .5 & \\
Total m3/hari & 106.410 & 178.725 & 136.155 & 64.624 & 50.5422 & 536.336 \\
Total kg/hari & 266,025 & 446,8125 & 340,3875 & 161,56 & 126,055 & \\
\% Layanan & 53.205 & $89.362,5$ & $68.077,5$ & 32.312 & 25.211 & \\
Tdk terlayani m3/hari & $88 \%$ & $93 \%$ & $93 \%$ & $72 \%$ & $79 \%$ \\
Tdkk terlayani kg/hari & 35,5 & 33,15 & 24,1475 & 61,3975 & 32,5425 & \\
\hline
\end{tabular}

\section{Komposisi sampah di Kota Surakarta}

Perbandingan komposisi sampah di

Kota Surakarta pada tahun 2013 terkomposisi sampah organik menempati persentairi dari se yang lebih tinggi daripada komposisi sampah yang lain yaitu sebesar 70,34\%.
Persentase komposisi sampah yang terkecil berasal dari karet/kulit yaitu sebesar 0,43\%. Komposisi sampah di Kota Surakarta disajikan pada Gambar 1 berikut: 


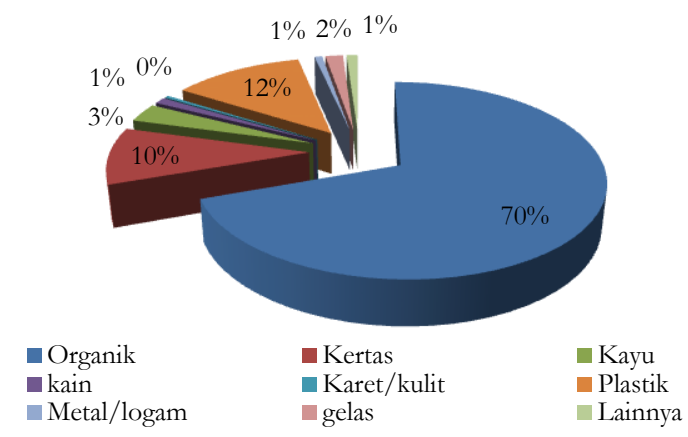

Gambar 1. Persentase Komposisi sampah Kota Surakarta

Gambar 1 tersebut menjelaskan mengenai perbandingan komposisi sampah di Kota Surakarta pada tahun 2013, komposisi sampah organik menempati persentase yang lebih tinggi daripada komposisi sampah yang lain yaitu sebesar $70,34 \%$. Persentase komposisi sampah yang terkecil berasal dari karet/kulit yaitu sebesar $0,43 \%$.

\section{Kualitas layanan Persampahan \\ Persentase Pelayanan}

Pada tahun 2013 jumlah penduduk Kota Surakarta yang mendapat layanan persampahan mencapai $86 \%$ dan diperkirakan akan meningkat menjadi $92 \%$ pada tahun 2022. Persentase tersebut menunjukan kualitas pelayanan persampahan di Kota Surakarta sudah sangat baik.

\section{Pengumpulan Sampah Di Kota Surakarta}

Pengumpulan sampah yang dilakukan dilakukan dengan menggunakan bak sampah. Sampah yang terkumpul diangkut dengan menggunakan gerobak sampah yang tersedia dan akan diangkut ke transfer depo atau TPS dan selanjutnya Sampah yang sudah diangkut menuju ke TPA Putri Cempo.

\section{Pemindahan Sampah di Kota Surakarta}

Operasional Pemindahan sampah dilakukan dengan menggunakan pola pemindahan tidak langsung, yaitu sampah dikumpulkan terlebih dahulu TPS, kemudian Sampah yang terkumpul langsung dibawa ke TPA, operasional berlangsung pada pukul 05.00 - 14.00 wib. Jumlah TPS yang tersedia berjumlah 55 buah.

\section{Pengangkutan Sampah}

Operasional pengangkutan sampah di Kota Surakarta, dilakukan dari berbagai Tempat Pembuangan Sampah yang ada di Kota Surakarta dengan menggunakan truk sampah dan dilakukan 3 kali sehari pada pukul 05.30, 12.30, dan 15.30, apabila ada sampah yang masih menumpuk, maka sampsh yang tertinggal akan diangkut pada keesokan harinya, mengingat waktu operasional hingga pukul 04.00 sore, jadi sampah akan tinggal di TPS selama 14 jam. Untuk operasi pengangkutan sampah di Kota Surakarta yaitu

a. Sampah dari pemukiman yang telah terkumpul di bak TPS, dan dari TPS diangkut dengan truk sampah untuk selanjutnya dibuang ke TPA Putri cempo.

b. Sampah komersial pertokoan dikumpulkan dan di buang di wadah sampah yang ada di depan toko masingmasing, kemudian diangkut ke TPA

\section{Lokasi Tempat pembuangan sementara (TPS) di Kota Surakarta}

Lokasi TPS di Kota Surakarta tersebar di 5 kecamatan, yang mengalami pengurangan jumlah TPS dari tahun ketahun. Menurut Suletra. dkk (2009) TPS yang tersebar di Kota Surakarta dialokasikan untuk beberapa RW yang ada di Kota Surakarta.

Tabel 2. Usulan Alokasi sampah RW ke TPS pada tahun 2009-2013

\begin{tabular}{lll}
\hline No & \multicolumn{1}{c}{ Nama TPS } & \multicolumn{1}{c}{ Wilayah RW yang dilayani } \\
\hline 1 & Sampangan barat & Pasar Kliwon Rw 1, 2,3, 3, Kedung lumbu Rw 1, Semanggi RW: 16,17, 18, 19, 20 \\
2 & Sampangan timur & Sangkrah RW 8, 9, 10, Semanggi RW 1, 2, 3, 22 \\
3 & Silir & Semanggi RW 4, 5, 6, 10 \\
4 & Semanggi & Joyosuran 2, Pasar Kliwon:12, Semanggi: 12, 13, 14, 15, 18 \\
5 & Hadijayan & Baluwarti RW 1, 2, 4, 5, 6, 7, 8, 9, 10, 11, 12 \\
& & Gajahan RW 1, 2, 3, 4, 9, Joyosuran RW 1, Pasar Kliwon RW 6,7,8,9,10,11, \\
& & Danakusuman RW 2, 3, 4 \\
6 & Sadinu & Keprabon RW: 1, 2, 3, 4, 5, 6, Setabelan RW: 7, 8, 9 Kampung Baru RW: 5, Kauman \\
& & RW: 1, 3 Kemlayan RW: 1 \\
7 & Balai kota & Kampung baru RW: 6, Kauman RW: $4,5,6$ \\
\hline
\end{tabular}




\begin{tabular}{|c|c|c|}
\hline & & Kedung lumbu RW: 2, 4, 5, 6, 8, Pasar kliwon RW: 5 \\
\hline 8 & Joyontakan & Joyosuran RW: 5, 7, 9, 10, 11, 12, Joyontakan RW: 2, 3, 4, \\
\hline 9 & Dawung & $\begin{array}{l}\text { Joyosuran RW : } 6 \text { Danukusuman RW : 5, 6, 7, 8, 9, 10, 11, 12, 13, 14, } 15 \text { Joyotakan } \\
\text { RW : } 1 \text {, Serengan RW : } 11,14,15\end{array}$ \\
\hline 10 & Makam bergola & Serengan RW : 5, 6, 7, 8, 9, 10, 12, 13, Tipes RW : 10, 11 \\
\hline 11 & Tipes & Panularan RW : 2, 4 Tipes RW : 4, 6, 7, 8, 9, 12, 13, 14, 15 \\
\hline 12 & Mugen lepas & $\begin{array}{l}\text { Gajahan: 5, 6, 7, 8, Danukusuman: } 1 \text { Jayengan: 9, Kratonan RW: 1, 2, 4, 5, } 6 \\
\text { Serengan RW: } 1,2,3 \text {, } 4 \text {,Tipes RW: } 5\end{array}$ \\
\hline 13 & Kartopuran & Panularan RW : 6, 8, Jayengan RW : 2, 3, 4, 5, 6, 7, 8 \\
\hline 14 & Mugono & $\begin{array}{l}\text { Panularan RW : 6, 8, Jayengan RW : 2, 3, 4, 5, 6, 7, } 8 \\
\text { Kratonan RW : 3, Tipes RW : } 1,3\end{array}$ \\
\hline 15 & Spsa & Manahan RW: 13, Jajar RW: 1 Kerten RW: 2, 3, 4, 5, 6, 7 \\
\hline 16 & Panti waluyo & Kerten RW : 1, 13, Pajang RW : 10, 11, 12 \\
\hline 17 & Norowangsan & Karangasem RW : 1, 2, Pajang RW : 13, 16 \\
\hline 18 & Perum becak & Karangasem RW : 3, 5, 6, 9 \\
\hline 19 & Sondakan kuburan & Sondakan RW : 1, 2, 3, 4, 5, 6, 7, 8, 15 \\
\hline 20 & Sondakan I & Sondakan RW : 9, 10, 11, 12, 13, 14 \\
\hline 21 & Pajang rel & Pajang RW : 5, 6, 7, 8, 14 \\
\hline 22 & Pajang gentan & Pajang RW : 1, 2, 3, 4 \\
\hline 23 & Mangkuyudan I & Bumi RW: 5, 6,Panularan RW: 1, Penumping RW: 4, 5 \\
\hline 24 & Mangkuyudan II & Purwosari RW : $2,4,8$ \\
\hline 25 & Mangkuyudan III & Bumi RW : 1, 2, 3, 4, 7, Purwosari RW : 3, 5, 6, 7 \\
\hline 26 & Brengosan & Purwosari RW : 9, 10, 11, 12, 13, 14, Sondakan RW : 1 \\
\hline 27 & Samsat & Jajar RW : 2, 3, 4, 5, 6, 7, 8, Karangasem RW : 4 \\
\hline 28 & Pramuka & $\begin{array}{l}\text { Ketelan RW : 7, 8, Mangkubumen RW : } 12,13,14 \\
\text { Punggawan RW : 5, Timuran RW : } 1,2,3,4,5 .\end{array}$ \\
\hline 29 & Kretek bang & Mangkubumen RW : 3, 7, Punggawan RW : 2, 3, 4, 6 \\
\hline 30 & Sambeng & Gilingan RW : 1, 2, 3, 4, 7, Manahan RW : 1 \\
\hline 31 & Tirtonadi & Gilingan RW : $5,13,14,15$, Nusukan RW : 18,19 \\
\hline 32 & Depok & Manahan RW: 4, 5, 6, 7, 8 \\
\hline 33 & Dr.yeni & Manahan RW: 2, Nusukan RW : 6, 7,Sumber RW : 2, 3, 4 \\
\hline 34 & Manahan jam & Sumber RW : 5, 6, 7, 8, 12 \\
\hline 35 & SSS & Manahan RW : $10,11,12$ \\
\hline 36 & Sumber BK & Banyuanyar RW: 6, 9, 12 Sumber RW:13, 14, 15, 16,17 \\
\hline 37 & Minapadi & $\begin{array}{l}\text { Kadipiro RW : } 16,17 \\
\text { Nusukan RW : } 1,2,3,4,9,10,11,12,13,14,15,16,17\end{array}$ \\
\hline 38 & Bonoloyo & Kadipiro RW : 4, 10, 11, 12, 13, 14, 15, 22, 23, 24, 25, 26 \\
\hline 39 & Ngemlak & Gilingan RW: 17, Kadipiro RW: 18, 19, 20 Nusukan RW: 20, 21, 22, 24 \\
\hline 40 & BKIA & Gilingan RW : 12, Setabelan RW : 1, 2, 3, 4, 5, 6, Kepatihan Kulon RW : 1, 2 \\
\hline 41 & Hotel Ds & Kestalan RW : 1, Ketelan RW : 4, 5, 6, 9 \\
\hline 42 & Marconi & $\begin{array}{l}\text { Gilingan RW : } 6,8,9,10,11 \text {, Kestalan RW : 2, 3, 4, 5, } 6 \\
\text { Ketelan RW : 1, 2, 3, Punggawan RW : } 1\end{array}$ \\
\hline 43 & Turisari & $\begin{array}{l}\text { Manahan RW : 9, Mangkubumen RW : 4, 5, 6, 8, 9, 10, } 11 \\
\text { Penumping RW : } 1\end{array}$ \\
\hline 44 & Ringin Semar & Gilingan RW : 16, 18, 19, 20, Jebres RW : 1, 2, 3, 4, 30 \\
\hline 45 & $\mathrm{RC}$ & Jebres RW : 28, 29, 32, Mojosongo RW : 2, 7, 8, 9, 35 \\
\hline 46 & Uns cargo & Jebres RW : 5, 6, 9, 10, 11, 12, 23, 24, 25, 26, 27, 28 \\
\hline 47 & UNS & Jebres RW : 17, 18, 19, 20, 21, 22 \\
\hline 48 & Jurug & Jebres RW : $14,15,16,36$ \\
\hline 49 & Sariwarna & $\begin{array}{l}\text { Jagalan RW : 8, 9, 10, 11, 12, Jebres RW : 7, 8, } 13 \\
\text { Pucangsawit RW : 2, 3,11, 14, } 15\end{array}$ \\
\hline 50 & Jurnasan & Pucangsawit RW : $1,9,10$ \\
\hline 51 & Nlipakan & $\begin{array}{l}\text { Jagalan RW : 14, 15, Pucangsawit RW : 4, 5, 6, 7, 8, 12, } 13 \\
\text { Sewu RW : } 1,2,3,5,6\end{array}$ \\
\hline 52 & Tanggul & $\begin{array}{l}\text { Gandekan RW : 1, 3, 9, Jagalan RW : } 13 \\
\text { Sewu RW : 4, 7, 8, } 9 \text { Sangkrah RW : } 1,2,6,7,11,12,13\end{array}$ \\
\hline 53 & Batoar & Jagalan RW: 1, 2, 3, 4, 5, 6, 7 Purwodiningratan RW : 4, 5, 6, 7, 8, 9, 10 \\
\hline 54 & PT.King & $\begin{array}{l}\text { Kepatihan wetan RW: 1, 2, Kepatihan kulon RW: } 3 \text { Purwodiningratan RW : 2, 3, } \\
\text { Sudiroprajan RW : 6, 7, 8, } 9\end{array}$ \\
\hline 55 & Mojosongo & $\begin{array}{l}\text { Kadipiro RW : } 21,27 \\
\text { Mojosongo RW : } 12,13,14,15,20,21,22,23,27,31,32\end{array}$ \\
\hline 56 & Kerkop & $\begin{array}{l}\text { Gandekan RW : 2, 4, 5, 6, 7, 8, Purwodiningratan RW : } 1 \text { Sudiroprajan RW: 1, 2, 3, } \\
\text { 4, 5, Kedung lumbu RW: } 3,7\end{array}$ \\
\hline 57 & Panti kosala & Gilingan RW: 21, Nusukan RW : 23, Jebres RW : 31, 33, 34, 35 Mojosongo RW : \\
\hline
\end{tabular}




\begin{tabular}{lll}
\hline & & $1,3,4,5,6$, Tegalharjo RW $: 1$ \\
58 & Silir baru & Joyosuran: $3,4,8$, Semanggi: $9,11,23$ Joyosuran RW: 9 \\
59 & Sondakan II & Laweyan RW $: 1,2,3$, Pajang RW :9, 15 \\
60 & Ken dedes & Karangasem RW $: 7,8$ \\
61 & Sriwedari & Panularan RW: $3,5,7$, Penumping RW: $2,3,6$, Sriwedari RW : 1, 3, 5, 6, \\
& & Kemlayan RW $: 6$, Tipes RW $: 2$ \\
62 & Komplang & Banyuanyar RW $: 1,2,3,7,8,10,11$, Kadipiro RW : $1,2,3,5,6,7,8,9$, Nusukan \\
& & RW $: 5$, Sumber RW $: 1$ \\
\hline
\end{tabular}

Sumber: Suletra et al., 2009

Ket $: \square$ Lokasi TPS yang sudah di hapuskan pada tahun 2013, menurut Dinas DKP Kota

Suletra. dkk (2009) mengatakan usulan alokasi sampah wilayah RW ke TPS pada tahun 2009 yaitu 62 TPS (lihat Tabel 2), namun saat ini jumlah TPS di Surakarta yaitu 55 TPS.

\section{Sistem Pembuangan Akhir}

Sampah dari seluruh wilayah Kota Surakarta, akan diangkut dan berakhir di TPA putri cempo. TPA putri cempo masih menerapkan sistem open dumping, karena sampah hanya di kumpulkan dan tidak ada proses pemilahan sampah.

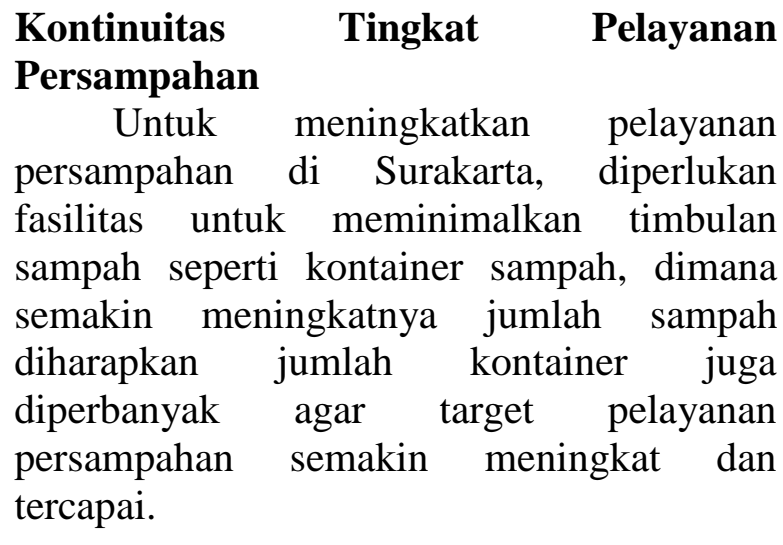

Tabel 3. Kebutuhan Kontainer sampah Kota Surakarta tahun 2013 - 2022

\begin{tabular}{cccccccc}
\hline Tahun & $\begin{array}{c}\text { Penduduk } \\
\text { Terlayani }\end{array}$ & $\begin{array}{c}\text { Penduduk } \\
\text { Total }\end{array}$ & $\begin{array}{c}\text { L/org/ } \\
\text { hari }\end{array}$ & $\begin{array}{c}\text { Sampah } \\
\text { /minggu }\left(\mathrm{m}^{3}\right)\end{array}$ & $\begin{array}{c}\text { Sampah rerata } \\
\text { /hari }\left(\mathrm{m}^{3}\right)\end{array}$ & $\begin{array}{c}\text { Kontainer sampah } \\
40 \%\left(\mathrm{~m}^{3}\right)\end{array}$ & $\begin{array}{c}\text { Total Jumlah } \\
\text { Kontainer }\end{array}$ \\
\hline 2013 & 536336 & 611031 & 2.36 & 8865.8 & 1478 & 591 & 131 \\
2014 & 547570 & 620515 & 2.45 & 9377.8 & 1563 & 625 & 139 \\
2015 & 559040 & 630147 & 2.53 & 9919.4 & 1653 & 661 & 147 \\
2016 & 570749 & 639929 & 2.63 & 10492.2 & 1749 & 699 & 155 \\
2017 & 582704 & 649862 & 2.72 & 11098.2 & 1850 & 740 & 164 \\
2018 & 594910 & 659949 & 2.82 & 11739.1 & 1957 & 783 & 174 \\
2019 & 607371 & 670193 & 2.92 & 12417.0 & 2069 & 828 & 184 \\
2020 & 620093 & 680596 & 3.03 & 13134.1 & 2189 & 876 & 195 \\
2021 & 633082 & 691161 & 3.13 & 13892.4 & 2315 & 926 & 206 \\
2022 & 646343 & 701889 & 3.25 & 14695.0 & 2449 & 980 & 218 \\
\hline
\end{tabular}

Timbulan Sampah yang Dikelola dengan 3R

Timbulan sampah yang dikelola dengan Konsep Reduce, Reuse dan Recycle (3R) adalah timbulan sampah yang dihasilkan dan terangkut ke TPA setiap orang/hari. Lebih lanjut dapat dilihat pada Tabel 4.

Tabel 4. Timbulan Sampah Domestik Terlayani pada Tahun 2013-2022 (dengan Penerapan Konsep 3R)

\begin{tabular}{|c|c|c|c|c|c|c|}
\hline \multirow{2}{*}{ No } & \multirow{2}{*}{ Timbulan sampah } & \multicolumn{5}{|c|}{ Tahun pertama } \\
\hline & & 2013 & 2014 & 2015 & 2016 & 2017 \\
\hline 1 & Jumlah Penduduk Total (jiwa) & 611.0 & 620.5 & 630.147 & 659.929 & 649.862 \\
\hline 2 & Jumlah Penduduk Terlayani (Jiwa) & 536.336 & 547.5570 & 559.040 & 570.749 & 582.704 \\
\hline 3 & Persentase Sampah Terlayani (\%) & $88 \%$ & $88 \%$ & $89 \%$ & $89 \%$ & $90 \%$ \\
\hline & Timbulan sampah & & & & & \\
\hline 1 & Timbulan Perkapita (ltr/hari) & 2,50 & 2,50 & 2,50 & 2.50 & 2,50 \\
\hline 2 & Timbulan Sampah Terlayani (m3/hari) & $1.340,8$ & $1.368,9$ & $1.397,60$ & $1.426,87$ & $1.456,76$ \\
\hline 3 & Timbulan Sampah Domestik Terlayani (m3/hari) & $1.005,6$ & $1.026,6$ & $1.048,20$ & $1.070,16$ & $1.092,57$ \\
\hline 4 & Timbulan Sampah Non Domestik Terlayani (m3/hari) & 335,21 & 342,23 & 349,40 & 356,72 & 364,19 \\
\hline 5 & Persentase $3 \mathrm{R} \%$ & 15 & 20 & 26 & 26 & 29 \\
\hline 6 & Timbulan Sampah 3R (m3/hari) & 150,84 & 205,34 & 241,09 & 278.24 & 316,85 \\
\hline 7 & Timbulan Sampah yang di Buang ke TPA (m3/hari) & 854,79 & 821,35 & 807,11 & 791,91 & 775.73 \\
\hline
\end{tabular}




\begin{tabular}{|c|c|c|c|c|c|c|}
\hline & \multirow{2}{*}{ Timbulan sampah } & \multicolumn{5}{|c|}{ Tahun Kedua } \\
\hline & & 2018 & 2019 & 2020 & 2021 & 2022 \\
\hline 1 & Jumlah Penduduk Total (jiwa) & 659.949 & 670.193 & 680.596 & 691.161 & 701.889 \\
\hline 2 & Jumlah Penduduk Terlayani (Jiwa) & 594.910 & 607.371 & 620.093 & 633.082 & 646.343 \\
\hline 3 & Persentase Sampah Terlayani (\%) & $90 \%$ & $91 \%$ & $91 \%$ & $92 \%$ & $92 \%$ \\
\hline 4 & Timbulan Perkapita (ltr/hari) & 2,50 & 2,50 & 2,50 & 2,50 & 2,50 \\
\hline & Timbulan sampah & & & & & \\
\hline 1 & Timbulan Perkapita (ltr/hari) & 2,50 & 2,50 & 2,50 & 2.50 & 2,50 \\
\hline 2 & Timbulan Sampah Terlayani (m3/hari) & $1.487,27$ & $1.518,43$ & $1,550.23$ & $1,582.70$ & $1,615.86$ \\
\hline 3 & Timbulan Sampah Domestik Terlayani (m3/hari) & $1.115,46$ & $1.138,82$ & $1,162.67$ & $1,187.03$ & $1,211.89$ \\
\hline 4 & Timbulan Sampah Non Domestik Terlayani (m3/hari) & 371.82 & 379.61 & 387.56 & 395.68 & 403.96 \\
\hline 5 & Persentase $3 \mathrm{R} \%$ & 32 & 36 & 40 & 44 & 48 \\
\hline 6 & Timbulan Sampah 3R (m3/hari) & 356.95 & 409.98 & 465.07 & 522.29 & 581.71 \\
\hline 7 & Timbulan Sampah yang di Buang ke TPA (m3/hari) & 758.51 & 728.85 & 697.60 & 664.74 & 630.18 \\
\hline
\end{tabular}

Tabel 4 menjelaskan Timbulan sampah yang akan dikelola dengan penerapan 3R sehingga timbulan sampah dapat diminimalkan. Untuk timbulan sampah dengan konsep 3R di Kota Surakarta pada tahun 2013 sebesar 142,29 $\mathrm{m}^{3} /$ hari dan akan meningkat menjadi $755.74 \mathrm{~m}^{3} /$ hari pada tahun 2022. Selain itu jumlah timbulan sampah yang dibuang ke TPA pada tahun 2013 sebesar $807,42 \mathrm{~m}^{3} /$ hari akan menjadi $818.72 \mathrm{~m}^{3} /$ hari pada tahun 2022 .

\section{Pelayanan Persampahan Berbasis Sistem Informasi Lingkungan (SIL)}

Pelayanan Persampahan berbasis Sistem Informasi Lingkungan dibuat dengan menggunakan Sofware Arcview 3.3, dimana informasi persampahan di Kota Surakarta memuat data-data distribusi sampah (Tabel 5) dan di visualisasikan kedalam peta layanan lersampahan, dan Kota Surakarta memiliki persentase layanan yang sudah baik, yaitu sebesar 70-93\%.

Tabel 5. Data Distribusi Sampah di Kota Surakarta

\begin{tabular}{llllll}
\hline Keterangan & Laweyan & Banjarsari & Jebres & PS.Kliwon & Serengan \\
\hline Jumlah PendudukTotal & 120.610 & 191.985 & 145.814 & 89.183 & 63.439 \\
Penduduk Terlayani & 106410 & 178725 & 136155 & 64624 & 50422 \\
Jumlah TPS & 15 & 16 & 15 & 8 & 6 \\
liter/org/hari & 2,50 & 2,50 & 2,50 & 2,50 & 2,50 \\
Total sampah m3/hari & 301525 & 4799625 & 364535 & 2229575 & 1585975 \\
Kg/org/hari & 0,50 & 0,50 & 0,50 & 0,50 & 0,50 \\
Total sampah kg/hari & 60305 & 959925 & 72907 & 445915 & 317195 \\
Persentase layanan (\%) & $88 \%$ & $53 \%$ & $93 \%$ & $72 \%$ & $79 \%$ \\
Sampah tidak terlayani m3 & 35,5 & 33,15 & 24,1475 & 61,3975 & 32,5425 \\
Sampah tidak terlayani (kg/hari) & 7100 & 6630 & 4829,5 & 12279,5 & 6508,5 \\
Vol. sampah pasar/m2/hari (1) & 0,20 & 0,20 & 0,20 & 0,20 & 0,20 \\
Total Vol sampah (m3) & 3,951 & 9,565 & 4,2753 & 11,840 & 2,7794 \\
\hline
\end{tabular}

\section{Peta Layanan Persampahan Kec. Laweyan}

Kecamatan Laweyan mempunyai 15

TPS, dan kelurahan yang belum mendapatkan TPS yaitu Panularan dan Penumping. Kecamatan ini mempunyai penduduk total tahun 2013 sebesar 120.610 jiwa dan terlayani sebesar 106.410 jiwa dengan persentase pelayanan sebesar $88 \%$.

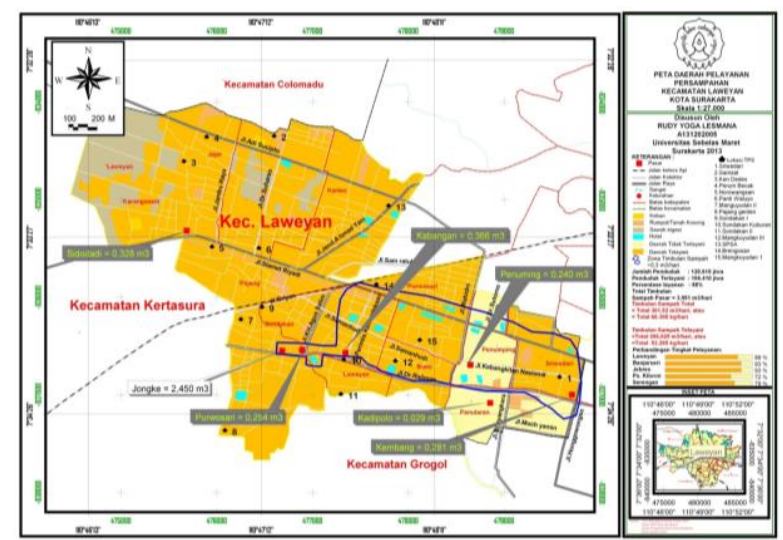

Gambar 2. Peta Pelayanan Persampahan Kecamatan Laweyan Kota Surakarta 
Timbulan sampah total 301,525 $\mathrm{m}^{3} /$ hari, dan timbulan sampah terlayani sebesar 266,025 $\mathrm{m}^{3} /$ hari. Timbulan sampah Pasar sebesar $3,951 \mathrm{~m}^{3} /$ hari. Sampah yang tidak terangkut sebesar $35,5 \mathrm{~m}^{3} /$ hari.

\section{Peta Layanan Persampahan Kec.Banjarsari \\ Di Kecamatan Banjarsari terdapat 16} TPS. Kelurahan yang belum mendapatkan TPS yaitu Panularan dan Penumping. Peta layanan persampahan Kec. Banjarsari dapat dilihat pada Gambar 3.

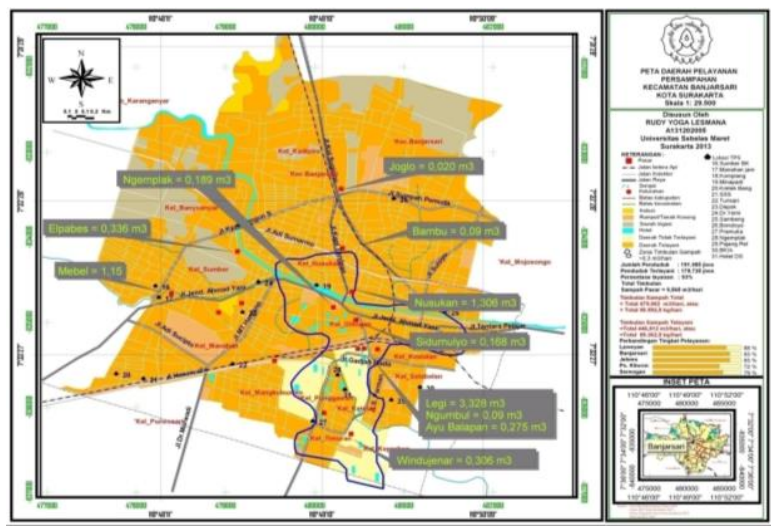

Gambar 3. Peta Pelayanan Persampahan Kecamatan Banjarsari Kota Surakarta

Kecamatan Banjarsari mempunyai penduduk total tahun 2013 sebesar 191.985 jiwa dan penduduk terlayani sebesar 178.725 jiwa. Timbulan sampah total 479,962 $\mathrm{m}^{3} /$ hari, dan sampah terlayani sebesar $446,8125 \mathrm{~m}^{3} /$ hari. Persentase pelayanan $93 \%$. Timbulan sampah Pasar sebesar 9,565 $\mathrm{m}^{3} /$ hari. Sampah yang tidak terangkut sebesar $33,15 \mathrm{~m}^{3} /$ hari.

\section{Peta Layanan Persampahan Kec. Jebres}

Kecamatan Laweyan terdapat 12 Tempat Tempat Pembuangan Sementara yang tersebar di berbagai Kelurahan di Kecamatan tersebut dan 1 TPA Putri Cempo, tetapi ada 1 kelurahan yang belum mendapatkan fasilitas TPS yaitu Kelurahan Gadengan. Kecamatan Jebres mempunyai persentase pelayanan persampahan sebesar 93\%. Kecamatan Jebres mempunyai jumlah penduduk sebesar 145.814 jiwa pada tahun 2013 dan penduduk terlayani sebesar 136.155 jiwa. Timbulan sampah total sebesar $364,535 \mathrm{~m}^{3} /$ hari, dan untuk timbulan sampah terlayani sebesar $340,3875 \mathrm{~m}^{3} /$ hari. Timbulan sampah yang berasal dari Pasar sebesar
4,2753 $\mathrm{m}^{3} /$ hari dan di kecamatan tersebut terdapat dalam 10 pasar. Sampah yang tidak terangkut yaitu sebesar $24,1475 \mathrm{~m}^{3} /$ hari. Lebih lanjutnya lihat Gambar 4.

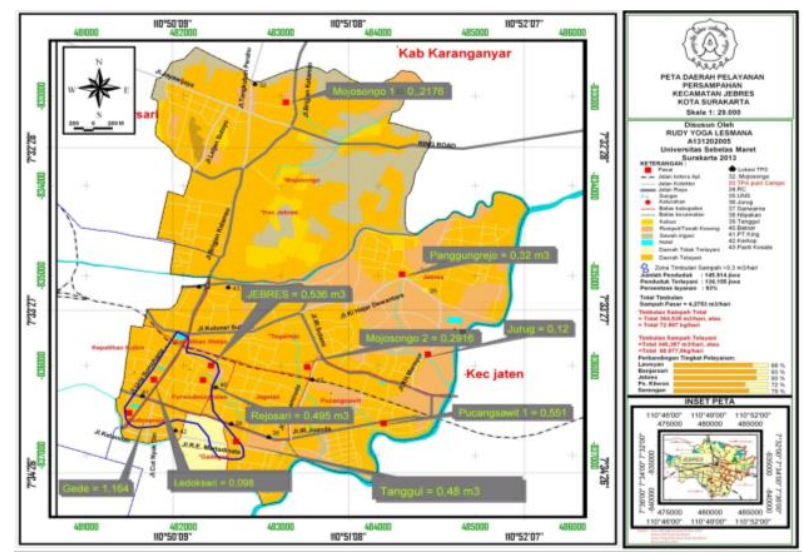

Gambar 4. Peta Pelayanan Persampahan Kecamatan Jebres Kota Surakarta

\section{Peta Layanan Persampahan Kecamatan Pasar Kliwon}

Di Kecamatan Pasar Kliwon terdapat 8 TPS, 1 pool kendaraan pengangkut sampah, dan ada 4 kelurahan yang belum mendapatkan fasilitas TPS yaitu kelurahan Joyosuran, Kauman, Kedunglumbu dan Pasar Kliwon. Kecamatan tersebut mempunyai persentase pelayanan sebesar $72 \%$ atau yang terkecil diantara empat Kecamatan yang ada di Kota Surakarta, dan hal ini disebabkan oleh banyaknya kelurahan yang tidak mendapatkan layanan persampahan. Peta Pelayanan Persampahan Kecamatan Pasar Kliwon Kota Surakarta dapat dilihat pada Gambar 5 berikut.

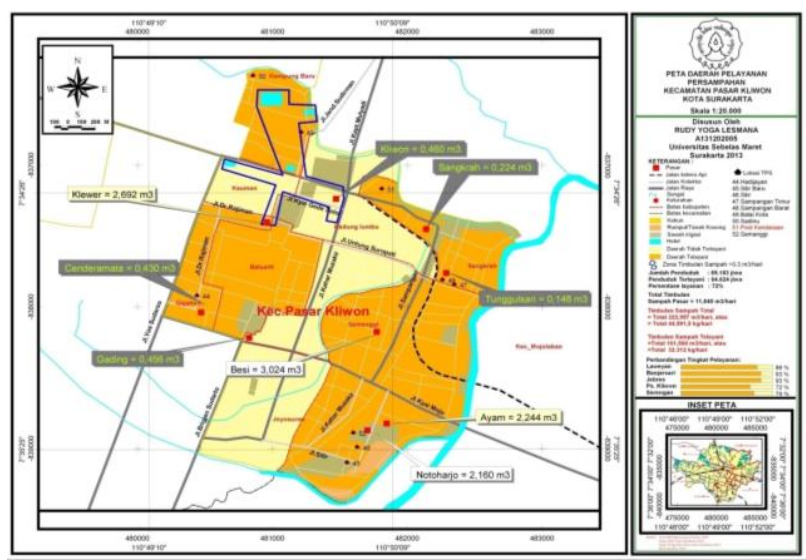

Gambar 5. Peta Pelayanan Persampahan Kecamatan Pasar Kliwon Kota Surakarta

Kecamatan Pasar Kliwon mempunyai penduduk total sebesar 89.183 jiwa pada tahun 2013 dan penduduk terlayani sebesar 64.624 jiwa. Untuk timbulan sampah total 
$222,957 \mathrm{~m}^{3} /$ hari. Untuk timbulan sampah terlayani sebesar $161,56 \mathrm{~m}^{3} /$ hari. Timbulan sampah yang dihasilkan dari Pasar yaitu sebesar $11,840 \mathrm{~m}^{3} /$ hari dan terbagi di dalam 9 pasar. Sampah yang tidak terangkut sebesar $61,3975 \mathrm{~m}^{3} /$ hari.

\section{Peta Layanan Persampahan Kecamatan Serengan}

Di Kecamatan Serengan terdapat 6 TPS yang tersebar di berbagai Kelurahan, dan ada 1 kelurahan yang belum mendapatkan layanan fasilitas TPS yaitu kelurahan Serengan. Kecamatan Serengan mempunyai persentase pelayanan sebesar $79 \%$.

Kecamatan Serengan dengan jumlah penduduk total pada tahun 2013 yaitu 63.439 jiwa dan penduduk terlayani fasilitas persampahan yaitu sebesar 50.422 jiwa. Untuk timbulan sampah total 158,597 $\mathrm{m}^{3} /$ hari, dan timbulan sampah terlayani sebesar $126,055 \mathrm{~m}^{3} /$ hari. Timbulan sampah yang dihasilkan dari Pasar yaitu sebesar 2,7794 $\mathrm{m}^{3}$ /hari dan terbagi di dalam 9 pasar. Sampah yang tidak terangkut yaitu sebesar $32,5325 \mathrm{~m}^{3} /$ hari. Lebih lanjutnya lihat Gambar 6.

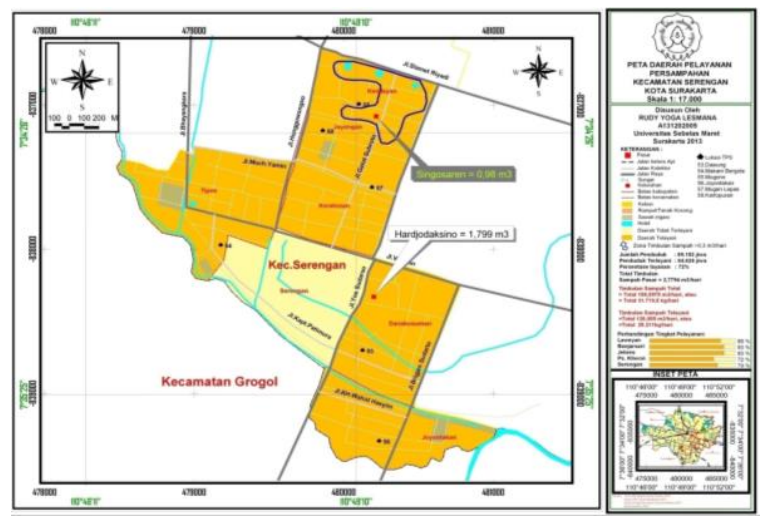

Gambar 6. Peta Pelayanan Persampahan Kecamatan serengan Kota Surakarta

\section{Rute Pengangkutan sampah di Kota Surakarta}

Rute pengangkutan sampah divisualisasikan dalam bentuk peta tematik, yaitu peta rute pengangkutan sampah Kota Surakarta, dan dapat dilihat perjalanan kendaraan pengangkut sampah, dimana kendaraan pengangkut sampah tersebut melewati lokasi TPS yang tersebar di lima kecamatan yang ada di Kota Surakarta, dan rute pengangkutan tersebut sebagai berikut:

\section{Kecamatan Laweyan}

Rute kendaraan pengangkut sampah di Kec. Laweyan dapat dilihat pada Gambar 7. Rute ini melewati Jl.Adi SuciptoJl.Jend.Ahmad Yani-Jl.Slamet Riyadi (Kleco)-Jl.Griyan-Jl. KH.Agus SalimJl.Samanhudi-Jl.Dr.Rajiman-Jl.Kabangkitan Nasional. TPS yang dilalui yaitu Sriwedari, Samsat, Hotel Kendedes, Perum Becak, Norowangsan, Panti Waluyo, Manguyudan II, Pajang gentan, Sondakan I, Sondakan Kuburan, Sondakan II, Mangkuyudan III, SPSA, Brengosan dan Mankuyudan I.

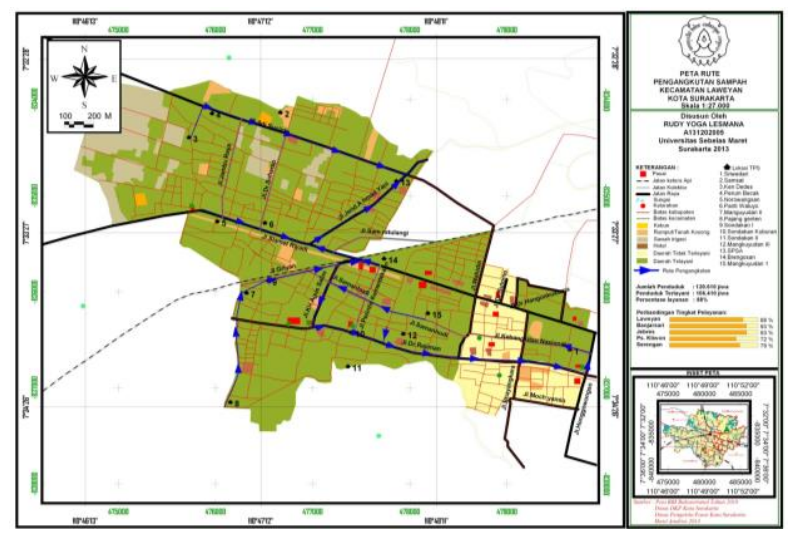

Gambar 7. Peta Rute Pengangkutan sampah Kecamatan Laweyan Kota Surakarta

\section{Kecamatan Banjarsari}

Rute Kendaran pengangkut sampah melewati J1. Kyai Mangun S-J1.Sumpah Pemuda-Jl.Jendral Ahmad YaniJl.Hasanudin-Jl.M.T. Haryono-Jl.Gadjah Mada-Jl.S. Parman. Tempat Pembuangan sementara (TPS) yang dilalui yaitu Sumber BK, Manahan Jam, Minapadi, Kretek Bang, SSS, Turisari, Depok, Dr.Yeni, Sambeng, Bonoloyo, Pramuka, Ngemplak, Pajang Rel, BKIA, dan Hotel DS. Peta rute ini dapat dilihat pada Gambar 8.

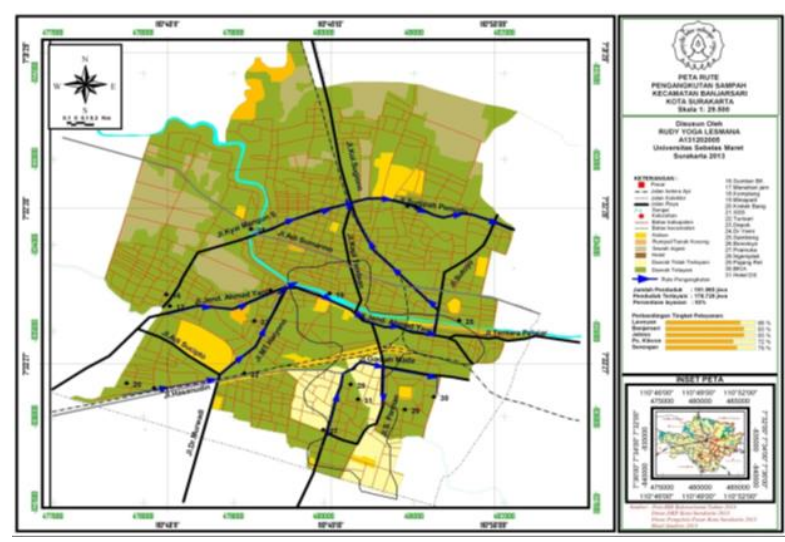

Gambar 8. Peta Rute Pengangkutan sampah Kecamatan Banjarsari Kota Surakarta 


\section{Kecamatan Jebres}

Peta rute pengangkutan sampah Kecamatan Jebres disajikan pada Gambar 9 berikut.

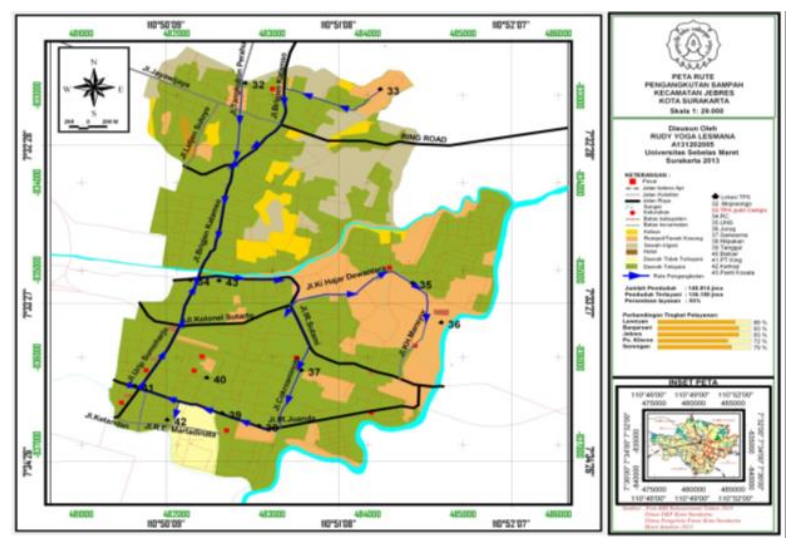

Gambar 9. Peta Rute Pengangkutan sampah Kecamatan Jebres Kota Surakarta

Rute Kendaran pengangkut sampah melewati Jl.Tangkuban Perahu- Jl.Brigjen Katamso (menuju TPA Putri Cempo)- Jl.Urip Sumoharjo- Jl.Ir.Juanda- J1. R.E. Martadinata- J1.Sutami- Jl.HOS. Cokroaminoto- Jl.Ki Hajar Dewantara- Jl. KH. Mansyur. Tempat Pembuangan sementara (TPS) yang dilalui yaitu Mojosongo, SMP RC, UNS, Jurug, Sariwarna, Nlipakan, Tanggul, Batoar, PT.King, Kerkop, Panti Kosala dan berakhir di TPA Mojosongo.

\section{Kecamatan Pasar kliwon}

Peta rute pengangkutan sampah Kecamatan Pasar Kliwon dapat dilihat pada Gambar 10 berikut.

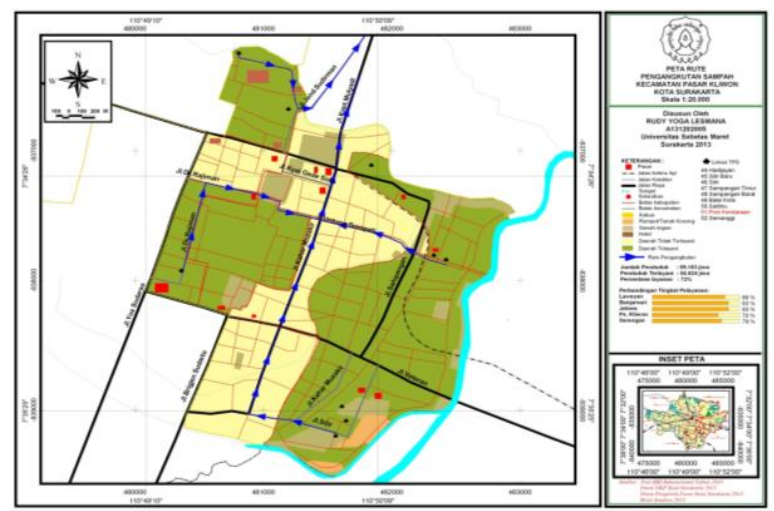

Gambar 10. Peta Rute Pengangkutan sampah Kecamatan Pasar Kliwon Kota Surakarta

Rute Kendaran pengangkut sampah melewati Jl.Jend. Sudirman- Jl.Kapt. Mulyadi- J1.Dr. Rajiman- Jl.Untung Suropati-
Jl. Kahar Muzakir- Jl.Silir. Tempat Pembuangan sementara (TPS) yang dilalui yaitu berawal dari pool Kendaraan, Hadijayan, Silir Baru, Silir, Sampangan Timur, Sampangan Barat, Balai Kota, dan Semanggi.

\section{Kecamatan Serengan}

Peta rute pengangkutan sampah Kecamatan Serengan dapat dilihat pada Gambar 11.

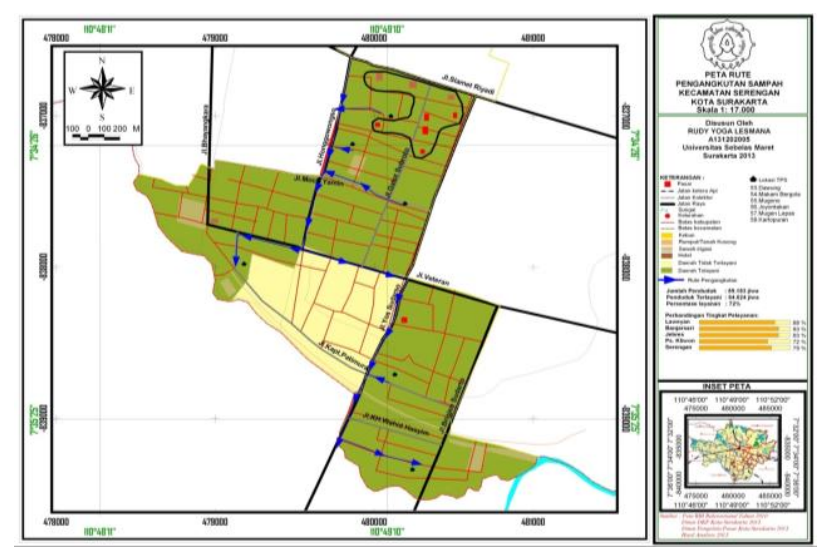

Gambar 11. Peta Rute Pengangkutan sampah Kecamatan Serengan Kota Surakarta

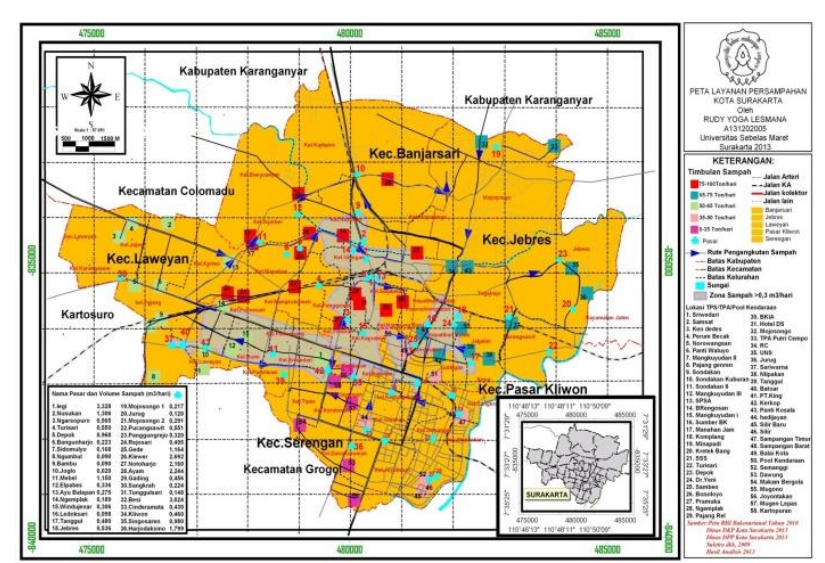

Gambar 12. Peta Layanan Persampahan Kota Surakarta

Rute Kendaran pengangkut sampah di Kecamatan Serengan melewati Jl. Honggowongso-Jl.Moch.Yamin- Jl. VeteranJl.Yos Sudarso. Tempat Pembuangan sementara (TPS) yang dilalui yaitu Dawung, Makam Bergola, Mugono, Joyontakan, Mugen Lepas, Kartopuran.

\section{KESIMPULAN}

1. Berdasarkan hasil analisis kondisi timbulan sampah yang berasal dari penduduk pada tahun 2013 yaitu sebesar 305,516 ton/hari, dengan tingkat 
pelayanan sebesar $88 \%$, dan diperkirakan akan mengalami kenaikan pada tahun 2022 sebesar $350.945 \mathrm{~kg} / \mathrm{hari}$ atau sebesar 350,945 ton/hari dan tingkat pelayanan diharapkan menjadi 92\%. Untuk jumlah timbulan sampah total (sampah penduduk dan pasar) pada tahun 2013 yaitu sebesar 321,72118 ton/hari.

2. Kualitas tingkat pelayanan persampahan yang berasal dari kegiatan penduduk (dengan tidak merperhitungkan kualitas layanan persampahan yang berasal dari sampah pasar) di kota Surakarta pada tahun 2013 yaitu sebesar 86\%. Untuk persentase layanan pada tahun 2014 diperkirakan mencapai $88 \%$ dan akan mengalami peningkatan menjadi $92 \%$ pada tahun 2022 atau sebesar $1 \%$ per tahun. Hal ini menunjukan bahwa kualitas layanan persampahan untuk sampah yang berasal dari penduduk di kota Surakarta sudah cukup bagus, dan hal ini dikarenakan fasilitas persampahan sudah tersebar merata di kota Surakarta.

3. Dalam kaitannya dengan kontinuitas pelayanan persampahan yang ada di kota Surakarta, perlu diupayakan pengelolaan terhadap timbulan sampah tersebut, diantaranya adalah dengan penyediaan kontainer-kontainer sampah dan penerapan konsep Reduce, Reuse, And Recycle (3R) dan komposting, sehingga dampak dari timbulan sampah dapat diminimalkan.

4. Dengan menggunakan sistem informasi Geografis untuk layanan persampahan, maka masyararakat dapat mengetahui berbagai hal mengenai kondisi persampahan yang ada di kota Surakarta, baik itu jumlah timbulan sampah, komposisi sampah, lokasi Tempat pembuangan sementara sampah, maupun rute kendaraan pengangkut sampah. Pemetaan mengenai layanan persampahan di kota Surakarta diharapkan dapat menangani masalah persampahan dengan melihat peta layanan persampahan yang ada di kota Surakarta.

\section{SARAN}

1. Diharapkan pemerintah dan pihak swasta dapat mengembangkan sistem informasi Lingkungan yang lebih baik, guna kepentingan masyarakat di kota Surakarta.

2. Peran serta masyarakat perlu ditingkatkan dalam pengelolaan pelayanan persampahan untuk meningkatkan persentase layanan persampahan di tahun yang akan datang.

3. Untuk rekomendasi di masa yang akan datang, diharapkan mulai tahun 2014 tidak ada lagi pengelolaan tempat pembuangan akhir sampah dengan metode Open Dumping, dan harus digantikan dengan metode Sanitary landfill.

4. Pada tahun 2014, istilah untuk TPS dan TPA digantikan dengan Tempat Pemrosesan Sementara dan Tempat Pemrosesan Akhir.

\section{DAFTAR PUSTAKA}

Bahar, Yul H., 1986, Teknologi Penanganan dan Pemanfaatan Sampah, PT. Wacana Utama Pramesti, Jakarta.

Prahasta, E., 2002, Konsep-konsep Dasar Sistem Informasi Geografis, Informatika, Bandung.

Ratih, Yulita S. 2011. Evaluasi Metode Pengelolaan sampah untuk umur layan Di TPA Putri Cempo. Jurnal Penelitian, volume 12 no. 2 september 2011, hal. 41.

Sugiyono, 2011. Metode Penelitian Pendekatan Kuantitatif, Kualitatif, dan $R \& D$. Bandung: Alfabeta

Suletra, Wayan I. Liquiddanu, Eko. Pamungkas, Sigit Bagus, 2009, Optimasi Pengalokasian sampah wilayah ke tempat pembuangan sementara dengan model integer linear programming (Studi Kasus Kota Surakarta), Jurnal performa, vol.8, No.1: 14-22.

Tchobanoglous, George, Theisen, Hilary, Vigil, 1993, Integrated Solid Waste Management, Mc Graw-Hill, Singapura.

Undang-undang Republik Indonesia Nomor.18 Tahun 2008 Tentang Pengelolaan Sampah 